\title{
Spatial Character of Tokyo's Famous Tourist Attractions
}

\author{
Odilia Renaningtyas Manifesty \\ Department of Architecture and Planning, Faculty of Engineering, Universitas Gadjah Mada \\ odilia.r.m@ugm.ac.id
}

\begin{abstract}
Various competitiveness reports on tourism have ranked Japan as one of the most visited countries in Asia. Along with South Korea and Singapore, Japan offers many unique traits to the tourists. Since the establishment of "Kihinkai" (lit. Welcome Society), Japan's first organization to engage with foreign tourists, the country has succeeded in developing various sector in tourism such as heritage sites, naturebased tourism, religious sites, and urban tourism. Tokyo Metropolis, as the capital of Japan, is one of the best examples in urban tourism sector. Hotel occupancy in Tokyo has risen around $80 \%$ in the last decade, showing high growth of tourism in the city. The aforementioned growth is supported by many factors, with one of them being advanced development of tourist attractions. The paper examines the spatial aspect of Tokyo's nine most famous tourist attractions. The complexity of place, accessibility and the presence of surrounding amenities, as well as the ambience or atmosphere offered by the attractions are the components analyzed to form a set of characteristics that define the character of Tokyo's tourist attractions. The result shows that the samples offer wide range of spatial attributes intended for different type of users. The compiled data can be used as a precedent study or preliminary guideline for other big cities in Japan or Asia to develop their potential of urban tourism.
\end{abstract}

Keywords: urban tourism, spatial character, urban architecture

\section{Introduction}

Being a major metropolitan, Tokyo is not only famous for its financial activities. The flourishing tourism in 2000's contributes significantly to the city's economy (Sassen, 2001). The need for encouraging local people to travel for leisure activities, as well as for attracting more foreign tourists, have been heavily discussed by the government of Japan since the late $19^{\text {th }}$ century (Leheny, 2003). "Visit Japan Campaign" or locally known as kihinkai was launched shortly afterward after a long period of isolating themselves from the international forum and took effects on many cities in Japan in a form of advancement in tourism environment (Kurihara \& Okamoto, 2010). Ranking system conducted by Kurihara and Okamoto in 2010 shows that Japan sit in second position just behind Singapore, in term of positive points regarding tourism environment. Japan cities such as Tokyo, Osaka, Kyoto, and Sapporo develop several major tourist destinations that show unique character, for example Kyoto with its traditional Japanese feel and Sapporo with its back-to-nature concept. Tokyo, as the capital and gate of Japan, shows the concept of representing the nation through its tourism. In 2017, the government launched new slogan for Tokyo tourism: "Tokyo Tokyo Old Meets New", with the first 'Tokyo' is written in old style font and the second 'Tokyo' is written in modern style font. This indicates that Tokyo offers various experiences ranging from modern urban life to traditional Japanese architecture.

Jurnal RUAS Volume 17 No. 1 Juni 2019 ISSN 1693-3702 E-ISSN 2477-6033 
Henderson (2017) explored the impacts of Tokyo's attribute as Global City to its capacity as tourist destination. Public is often led to believe that global city status is always advantageous to urban tourism. However, his paper concluded that there is distinctiveness in Tokyo's urban tourism in which it was derived from its long history and complex urban context, meanwhile the global city status is shorter process of moving the city into international market. Attractiveness of Tokyo's urban tourism had been assessed by Ranaweerage, Arima, and Kikuchi (2018) through its historical dimension. The result shows five attributes: "seeing," "buying," "dining," "gathering," and "relaxing" to be the determinant factors of attractiveness. Through the study of urban development history, Horita (2018) remarked that urban tourism space in Japanese cities came all the way from massive urbanization period in post second world war era. Rapid development followed the high number of population resulting in better urban space that attracts tourists to come. In modern days, local people tend to be more active in managing their living space so that the infill tourism function does not interfere with the residential area. Furthermore, collaborative management from the locals was established to make sure the urban tourism is beneficial to them as well. Those researches more focus on messo to macro scale of urban tourism design and planning. As a complimentary to the aforementioned studies, this paper examines smaller details which is the spatial characters of each sample of urban tourism destination.

\subsection{Urban Tourism in Tokyo}

Co-existence between tourism and non-tourism purpose that beneficial towards the community has become one advantage of urban tourism. This advantage is shown in Tokyo where tourists can feel unique life of the city and the locals can get more financial opportunities. Moreover, balance mixture of modernism and traditionalism has made Tokyo very popular for wide range group of tourists. Younger visitors often feel attracted by the city's modern urban landscape; meanwhile more senior visitors tend to enjoy unique culture and natural beauty of Tokyo (World Tourism Cities Federation, 2017). For ten years, the number of inbound tourist in Tokyo always shows significant inclination for almost each year since 2008. The only year that the number ever went down was in 2011, when earthquake disaster followed by tsunami hit the northeast coastline of Japan (Tokyo Metropolitan Government, 2018) . However, the very next year, the number had climbed the chart again, thanks to the effort made by the Tokyo Metropolitan Government (TMG) that always put tourism one of their main priorities. In 2015, the government set numerical target to double the number of inbound tourists in 2020, following Tokyo's appointment as host of Olympic and Paralympic Games 2020.

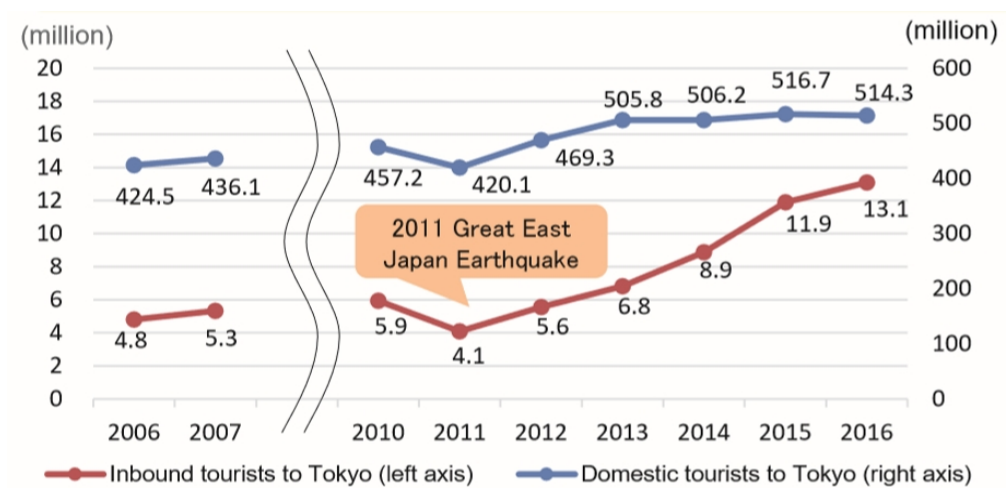

Figure 1. Number of tourists visiting Tokyo

(Source: Tokyo Metropolitan Government, 2018)

Jurnal RUAS Volume 17 No. 1 Juni 2019 ISSN 1693-3702 E-ISSN 2477-6033 
Six strategies were formulated by the TMG to achieve the ambitious target. The strategies are followed by several key points for each strategy with the main focus is on tourism planning and enhancement of revenues. However, since form and space play an important part in tourism development, architecture and urban design aspects are also mentioned in the strategies. For example is the promotion of ryokan or traditional Japanese inns to more foreign visitors. This point aims to generate more accommodation options for the tourist. The next strategy is to enhance the attractiveness of Tokyo's bay area as tourist destination, the planning point for this area include Yokohama, Tennozu, and Kunitachi. As a country famous for anime ${ }^{1}$, Tokyo has several spots that are frequently used as anime setting. This potential is emphasized to attract more tourists since anime is getting more and more popular around the world. Integration between tourist amenities and tourist destinations comes next on the strategy list. For example in Tama area, there is solid integration between accommodation, commercial, business, and leisure facilities. Shinjuku area shows similarity with the emphasis on the leisure facility, where you can find natural tourist spot, nightlife entertainment, offices, and traditional Japan-themed architecture in close proximity.

Senior citizens and people with disabilities are getting more attention in Tokyo tourism development. It shows that universal design becomes one of the strategies to attract more visitors. Since Tokyo is famous for visitors who come with their family, the application of universal design will add more comfort to their journey. Last but not least, the last effort on encouraging more tourists to visit Tokyo is expanding the tendency of municipality's collaboration in forming tourism in greater Tokyo area. Currently, Central Tokyo, along with Yokohama and Odaiba, is forming one package of tourist destination. The proximity closeness and the integration of metro system between those areas are the key to expanding the stated collaboration.

\subsection{Spatial Character in Tourist Destination}

Architecture has played an important role on shaping and promoting urban tourism throughout the world. The most evident way on how architecture helps turning an urban area into tourist destination is shown by the high number of tourists that are attracted by local buildings or monuments (Cegar, 2014). This phenomenon is seen in European cities like Rome, Paris, and Athens. These cities have famous monumental buildings that shape the cities identities. With the advancement of technology in architecture, the attraction is not limited to historical buildings but also the product of modern architecture. For examples are cities like Dubai and Singapore, where exorbitant high rises and waterfront attract people to enjoy the city life. Those cities are evidence that architecture has become one of tourism prominent commodity. As architecture scope is not limited to single building, larger context such as urban or precinct design is also able on attracting tourists. According to Edwards, Griffin \& Hayllar (2008), good physical form by means of architecture that creates identity to a place is able to pull people to visit specific precincts. According to e-Stat, a Portal Site of Official Statistics of Japan, 88\% visitors of Tokyo mention sightseeing as their visit purpose. This shows that Tokyo offers visual satisfaction through distinctive spatial character on its tourist attraction

Cited from Koran Merah, cyber news portal in Lombok, West Nusa Tenggara, there are currently 56 developing tourist villages spread around the island. The emergence phenomenon of tourist villages in Indonesia shows that there has been encouragement to turn a village which is usually a private neighborhood for the locals into something more

${ }^{1}$ Japan's original form of animation or cartoon.

Jurnal RUAS Volume 17 No. 1 Juni 2019 ISSN 1693-3702 E-ISSN 2477-6033 
public that able to welcome visitors. Beside the tendency of converting a private place into a public space, the inverse process could also happen usually in smaller scale architecture. For example there has been a surge in demand of private space in restaurant or the currently trending co-working space even though both places are categorized as public space (Manifesty \& Afif, 2018). In tourist destinations, there are places with distinct border between its public and private realm, others leave the border vague, and other destinations tend to be more public than private or vice versa. In the United States, there are a lot of public spaces that turns into urban tourist attraction, for example New York's Central Park, Chelsea's High Lane, and Chicago's Millenium Park (The Urban Phoenix, 2018). Several destinations in Tokyo convey the same form of urban tourist attraction as the aforementioned cities, some other destinations show various division of public and private realm.

Next thing that shapes the spatial character of tourist destination is the way it connects with the surrounding environment. When city has succeeded in fulfilling visitors need for leisure, it means that the city has turned into tourist destination (Giriwati, Homma, \& Iki, 2016). Other interpretation is that city as tourist destination offers whole product of tourism which is a combination of attractions and services. Following the stated combination, Clare A. Gunn in his book titled Tourism Planning: Basics, Concepts, and Cases, formulated spatial concept and its components for tourist destination. The concept shows tourist attraction as main element sits on the middle with exact border and surrounded by supporting elements which include accessibility to the destination, access between the destination and its surrounding, and nearby attractions and accommodations (Gunn, 2002). As Tokyo offers various kinds of tourist attractions, from traditional to modern style, it is interesting to examine the spatial pattern of the attractions.

The third characteristic involves the complexity of space and its relation to the space's functionality. One of mandatory qualities in architecture according to Vitruvius is about functionality. Several aspects need to be looked at to achieve functionality in an architecture work. The first aspect is related to the utility of a building or an area, such as the existence of fire protective and evacuation system in a high rise building is a must. The second aspect is about space integration within the precinct. Even a simple coffee shop must show good integration between space where the customers sit and enjoy their drinks with the space where the barista prepare the drinks. Some coffee shops have those two space integrated in one big room so that the customers would enjoy the coffeemaking process, others prefer to separate them completely by putting it into two rooms so that both function can have its own 'privacy. As a more complex place compared to the coffee shop analogy, to create good space integration in tourism precinct is mandatory since it plays a vital part in generating the visitors' spatial contextual awareness. Hence, it is more advised to make less complicated space arrangements in tourist destinations. It is because complexity is often associated with disorganized place in which people might get easily confused inside it (Salingaros, 2014).

Last but not least in spatial characteristic of tourist destination is about a destination image which is linked with the motive for tourist to visit a destination. Even though it is intangible, image of a place is the first driving tool for a tourist to select a destination (Baloglu \& W.McCleary, 1999). Destination image refers to general or specific ideas that a person has of a particular destination. Logically, every tourist has this destination image before they actually visit a destination. The source of the aforementioned image comes from wide range such as advertisement, stories from other people who have been to the destination, collected information from the media, and so on. Even though destination image is an image perceived by particular person, how a 
tourist attraction promotes itself plays an important role. The atmosphere or ambience created by the attraction gives impression to the person who sees the attraction, even just from a photograph. The person than translate it into their own destination image that influence their behavior intention (Pratt et al., 2017).

\subsection{Objective of the Study}

The aim of this research is to imperatively recognize the distinctive spatial feature(s) of Tokyo's famous tourist attractions. The analysis on this study tries to extract information from comparative study of several tourist attractions in Tokyo. In accordance with the research aim, several objectives are set for this publication: 1 . To gain better understanding of urban tourism development in Tokyo and; 2 . To gain insight on what actually makes several tourist attractions in Tokyo very attractive to tourists, from the perspective of architecture and urban design. From direct observation, there are at least four key attractions in Tokyo. They are temple and shrine, public parks, neighborhood, and landmark buildings. Samples of those key attractions are observed thoroughly to formulate list of spatial character of Tokyo's famous tourist attractions. The author wishes that the result of this study can be used as a supporting guideline for other potential cities to develop their urban tourism.

\section{Methodology}

Sampling method was conducted in this study to formulate the desired outcome. To decide the sample, study literature on Tokyo's key attraction mentioned on previous chapter was conducted and nine tourist destinations in Tokyo were chosen to be analyzed. According to Tokyo Tourism Strategy Action Plan 2017, tourism activity is most flourished at Shinjuku/Okubo, Asakusa, Ginza, Akihabara and Shibuya. Akihabara, Ueno, and Odaiba are Tokyo's second busiest districts in term of tourism (Tokyo Metropolitan Government, 2017). Nine destinations inside those areas are chosen to be the sample and to be analyzed regarding their spatial character. Those destinations are: (a) Shinjuku Gyoen, the largest national park of Tokyo area which famous for momiji ${ }^{2}$ and sakura viewing; (b) Shibuya Crossing, famous intersection that is often appear in anime and located in Shibuya, major commercial and business center. This crossing is also home to the famous Hachiko statue; (c) Omotesando, one of Tokyo's shopping street filled with luxurious shops; (d) Tokyo Tower, once was the tallest structure in Tokyo and today remains as notable landmark of the city; (e) DiverCity of Odaiba, shopping mall located at Odaiba, one of Tokyo's leading tourist spots, that combines Japan-themed goods and international brands. Since 2012, the front yard of the mall has been displaying a life-size Gundam $^{3}$ statue; (f) Odawara Castle, a magnificent symbol of Odawara City, closest city to Tokyo that can be reached by Shinkansen; (g) Yamashita Park, a waterfront park located at Yokohama, municipality near Tokyo that is well known as Japan's prominent port city; (h) Tokyo Skytree, the tallest structure in Tokyo that has become the city's newest landmark; (i) Sensoji Temple, one of the biggest and most significant Buddhist temple in Tokyo and Nakamise-dori, a street towards the temple that is filled with traditional Japanese shops.

All those tourist destinations are observed directly with qualitative and quantitative approach from four aspects. Qualitative approach includes descriptive explanatory from photos and place-centered mapping data. While quantitative approach

\footnotetext{
${ }^{2}$ When the leaves of certain trees turn red and yellow during the autumn season.

${ }^{3}$ Giant robot character from famous Japanese anime with the same title.
} 
includes calculation of the total topological depth of each destination. The first one is the division and distinction of public-private realm within those destinations. This aspect shows whether people can roam around the destinations freely or not (Georgiou, 2006). Moreover, it shows how permeable the destinations are for the visitors. The next aspect is related to accessibility and amenities. Tourism environment is mostly composed by two things, attractiveness and supporting services such as accommodation and transportation (Kurihara \& Okamoto, 2010). Based on Gunn's theory of spatial concept in tourist destination, this study looks upon those two things in the destinations which include main attraction of the each destination, nearby attractions (within the radius of $1 \mathrm{~km})$, main entrance(s), and metro or local train access. Data for this aspect is shown in series of radial maps with $1 \mathrm{~km}$ radius and the destination is placed at the center of the map. The third aspect is the complexity of space which is shown by simple space syntax analysis of total depth.

Total depth, calculated using justified graph, shows the topological depth from a specific node to other nodes within a place (Dawes \& Ostwald, 2013). For this study, the starting node is the nearest access to the destination. Higher total depth value indicates more 'rooms' are available within the destination and hence generates more complex relationship between each 'room'. The last aspect concerns about the ambience or atmosphere of the destination. This aspect describes the intended image of the destination, whether the destination creates atmosphere for a family vacation, urban life enthusiast, or for shoppers. Series of photographs is presented for this aspect, to get clear pictures of the ambience. Comparison of all four aspects is used to formulate the spatial character of Tokyo's famous tourist attractions.

\section{Result and Discussion}

\subsection{Distinction of the Public and Private Realm}

Based on direct observation on the location, the most common way on dividing the two realms is through the existing of entrance fee. Some areas are considered private if you need to pay to go inside and considered public if you don't have to pay to enjoy the destination. The level of privacy varies according the type of the ticket. Some tickets allow you to visit the destination repeatedly in one day; some others only allow you to go inside once per ticket per day. Other way on identifying the realms is through the type of the attraction itself. If the attraction takes form of buildings, for example a shopping mall, they usually display clear distinction of front and back of the house. Front of the house $(\mathrm{FoH})$ refers to space dedicated to the customers which can be considered public, whereas back of the house $(\mathrm{BoH})$ refers to space dedicated to the staffs which can be considered private. Below is the table showing the distinction of the public and private

realm in each attraction:

Jurnal RUAS Volume 17 No. 1 Juni 2019 ISSN 1693-3702 E-ISSN 2477-6033 
Table 1. Public and Private Realm Division in Tokyo's Famous Tourist Attraction

\begin{tabular}{|c|c|c|}
\hline Attraction & $\begin{array}{l}\text { Admission } \\
\text { Fee }\end{array}$ & Public-Private Realm \\
\hline Shinjuku Gyoen & $\begin{array}{l}200 \text { yen, all } \\
\text { area }\end{array}$ & $\begin{array}{l}\text { All public with the } \\
\text { payment of admission } \\
\text { fee }\end{array}$ \\
\hline Shibuya Crossing & Free & All public and free \\
\hline Omotesando Hills & Free & $\begin{array}{l}\text { All public and free } \\
\text { along the street. Clear } \\
\text { division of public and } \\
\text { private realm inside } \\
\text { the malls following the } \\
\text { BoH and FoH structure. }\end{array}$ \\
\hline Tokyo Tower & $\begin{array}{l}\text { Free (until } \\
\text { the } 5 \text { th floor), } \\
900 \text { yen } \\
\text { (main deck), } \\
\text { and } 2800 \text { yen } \\
\text { (main + top } \\
\text { deck) }\end{array}$ & $\begin{array}{l}\text { More private with } \\
\text { higher admission fee }\end{array}$ \\
\hline DiverCity of Odaiba & Free & $\begin{array}{l}\text { Clear division of public } \\
\text { and private realm } \\
\text { inside the malls } \\
\text { following the BoH and } \\
\text { FoH structure. }\end{array}$ \\
\hline Odawara Castle & $\begin{array}{l}650 \text { yen to } \\
\text { enter the } \\
\text { castle }\end{array}$ & $\begin{array}{l}\text { All public with the } \\
\text { payment of admission } \\
\text { fee }\end{array}$ \\
\hline Yamashita Park & Free & Mostly public \\
\hline Tokyo Skytree & 2060 yen & $\begin{array}{l}\text { Mostly public with } \\
\text { payment of admission } \\
\text { fee }\end{array}$ \\
\hline $\begin{array}{l}\text { Sensoji Temple and } \\
\text { Nakamise-dori }\end{array}$ & Free & Mostly public \\
\hline Summary & \multicolumn{2}{|c|}{$\begin{array}{l}\text { Most of Tokyo's famous tourist } \\
\text { attractions offer a public area where } \\
\text { people don't have to pay to enjoy the } \\
\text { place. However the size of the public } \\
\text { space differs from one another. }\end{array}$} \\
\hline
\end{tabular}

(Source: Author’s analysis, 2018)

\subsection{Accessibility and Surrounding Amenities}

Based on literature study, these two elements are supporting one of tourism products, services. Accessibility of certain destinations can be observed from two points, the first one is in micro scale which concerns the entrance(s) of the tourist attraction. Most of the attractions have more than one entrance, showing high permeability. Others show less entrance, following higher privacy as indicated on point 3.1. The second point refers to macro scale which concerns on how people get to the destination. In the case of Tokyo, the macro scale accessibility relates to the availability of nearby metro station. Similar to micro scale accessibility, the number of nearby metro stations also varies. Some has only one direct metro station and others have more than one local station.

Beside accessibility, services in urban tourism are related to amenities. In this study, definition of amenities is limited to nearby, more localized tourist attractions. The objective is to relate with the previous accessibility point. The place-centered mapping shows that there are several other attractions around the subject within 1 kilometer radius. It indicates if tourists visit a subject, they will be able to explore other attractions

Jurnal RUAS Volume 17 No. 1 Juni 2019 ISSN 1693-3702 E-ISSN 2477-6033 
easily on foot. Below is the table showing the accessibility and amenities feature for each attraction:

\section{Table 2. Accessibility and Nearby Attractions around Tokyo's Famous Tourist Attraction}

\begin{tabular}{|c|c|c|c|c|}
\hline Attraction & Entrance(s) & $\begin{array}{l}\text { Major Nearby } \\
\text { Attractions }\end{array}$ & $1 \mathrm{~km}$ radius map & Legend \\
\hline Shinjuku Gyoen & $\begin{array}{l}\text { Three gates: } 2 \\
\text { gates at the } \\
\text { north and } 1 \\
\text { gate at the } \\
\text { south. } \\
\text { Medium } \\
\text { permeability }\end{array}$ & $\begin{array}{c}\text { Hanazono Park, Tokyo } \\
\text { Toy Museum, } \\
\text { Takashimaya } \\
\text { (Shopping Mall), Meiji } \\
\text { Jingu (Sports Complex) }\end{array}$ & & $\begin{array}{l} \\
\text { : The Destination } \\
\text { : Metro Station } \\
\text { : Other Tourist Destination } \\
\text { : Entrance of The Destination }\end{array}$ \\
\hline Shibuya Crossing & $\begin{array}{c}\text { Completely } \\
\text { open space. } \\
\text { High } \\
\text { permeability }\end{array}$ & $\begin{array}{c}\text { Shibuya Hikari } \\
\text { (shopping mall), Konno } \\
\text { hachiman Gu Temple, } \\
\text { Cosmo Planetarium, } \\
\text { Center Gai and Koen } \\
\text { Dori (Shopping } \\
\text { Streets), Bunkamura } \\
\text { (Museum), and Spain } \\
\text { Slope (Pedestrian) }\end{array}$ & & \\
\hline Omotesando Hills & $\begin{array}{l}\text { Along the } \\
\text { street of } \\
\text { Omotesando. } \\
\text { High } \\
\text { permeability }\end{array}$ & $\begin{array}{c}\text { Several Art Museums, } \\
\text { Deveral Fancy } \\
\text { Restaurants,Takeshita } \\
\text { Dori (Shopping Street), } \\
\text { Oriental Bazaar } \\
\text { (Souvenir Shop), and } \\
\text { Meiji \& Togu Shrine }\end{array}$ & & $\begin{array}{l}\text { : The Destination } \\
\text { : Metro Station } \\
\text { : Other Tourist Destination } \\
\text { : Entrance of The Destination }\end{array}$ \\
\hline Tokyo Tower & $\begin{array}{l}\text { Along the } \\
\text { Tokyo Tower } \\
\text { street. } \\
\text { Medium } \\
\text { permeability }\end{array}$ & $\begin{array}{l}\text { Tomo Memorial Park, } \\
\text { Shiba Park, Zojoji } \\
\text { (temple), Roppongi } \\
\text { (entertainment } \\
\text { district) }\end{array}$ & & \\
\hline $\begin{array}{l}\text { DiverCity of } \\
\text { Odaiba }\end{array}$ & $\begin{array}{l}\text { Along the } \\
\text { street at the } \\
\text { north of } \\
\text { DiverCity. } \\
\text { High } \\
\text { permeability }\end{array}$ & $\begin{array}{c}\text { Museum of Maritime } \\
\text { Science, Metropolitan } \\
\text { Park, West and Center } \\
\text { Promenade, Fuji TV } \\
\text { Building } \\
\text { (entertainment } \\
\text { district), Pallete Town } \\
\text { (shopping mall), } \\
\text { Aomichoufuto Park }\end{array}$ & & \\
\hline Odawara Castle & $\begin{array}{l}\text { Three gates: } 1 \\
\text { gate at the } \\
\text { north, } 1 \text { at the } \\
\text { west, and } 1 \text { at } \\
\text { the south. } \\
\text { Medium } \\
\text { permeability }\end{array}$ & $\begin{array}{l}\text { Hotoku and Odawara } \\
\text { Museum, Harune } \\
\text { Odawara (shopping } \\
\text { mall), Komine Garden, } \\
\text { Several Buddhist } \\
\text { Temple, Entrance to } \\
\text { Hakone }\end{array}$ & & \\
\hline
\end{tabular}




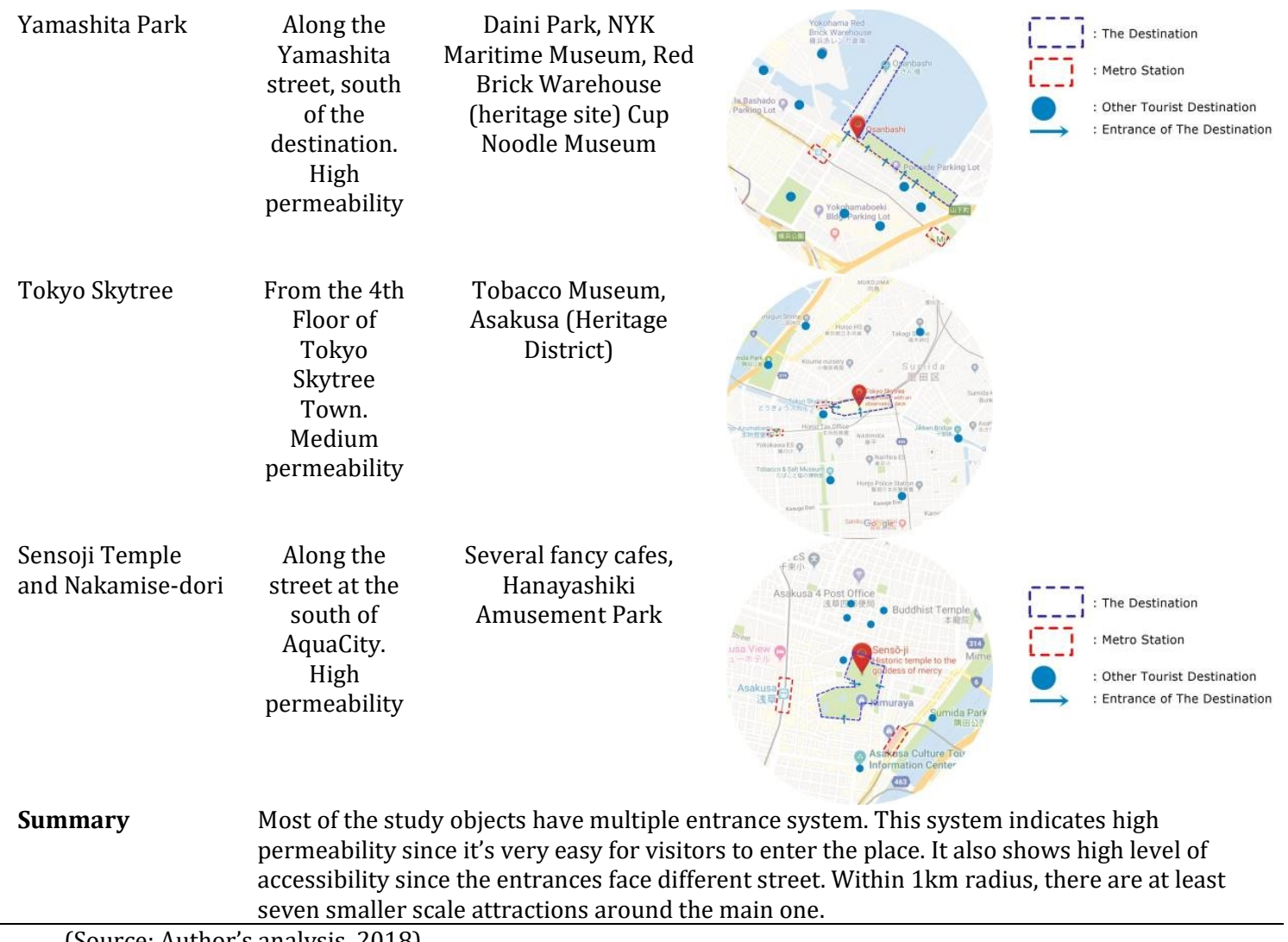

(Source: Author's analysis, 2018)

\subsection{Complexity of Space}

It is stated on the literature study that one aspect to be considered regarding the functionality in architecture is space integration. The space integration is related to visitor's spatial awareness which is very important in a tourist attraction. Space syntax approach is used to find the Total Depth (TD) value of the attractions. Higher TD value indicates more complexity and less space integration. The samples show different TD values and the range is quite wide between the lowest values to the highest one. The attractions that have lowest values are Shinjuku Gyoen and Yamashita Park. Both are functioning as public space as well as tourist attraction. This might be the reason for the low TD value in public parks, since they usually have few separated spaces that make the complexity of the place tend to be low. Moreover, public space is required to provide easy navigation for the people to enjoy.

The highest TD values are found in commercial-related tourist attractions. Places like malls and towers have many 'rooms' occupied by various tenants, thus integration among the 'rooms' are harder to achieve. In the middle, there are attractions that have medium TD value. Shibuya Crossing, Odawara Castle, and SensoJi Temple show this characteristic. Those places can be considered as public space, but compared to Shinjuku Gyoen and Yamashita Park, those places are more tourist oriented (Japan National Tourism Organization, 2017). Thus, have more commercial spaces and generate more complexity. 
Table 3. Justified Graph Analysis (from Entrance) on Tokyo's Famous Tourist Attraction

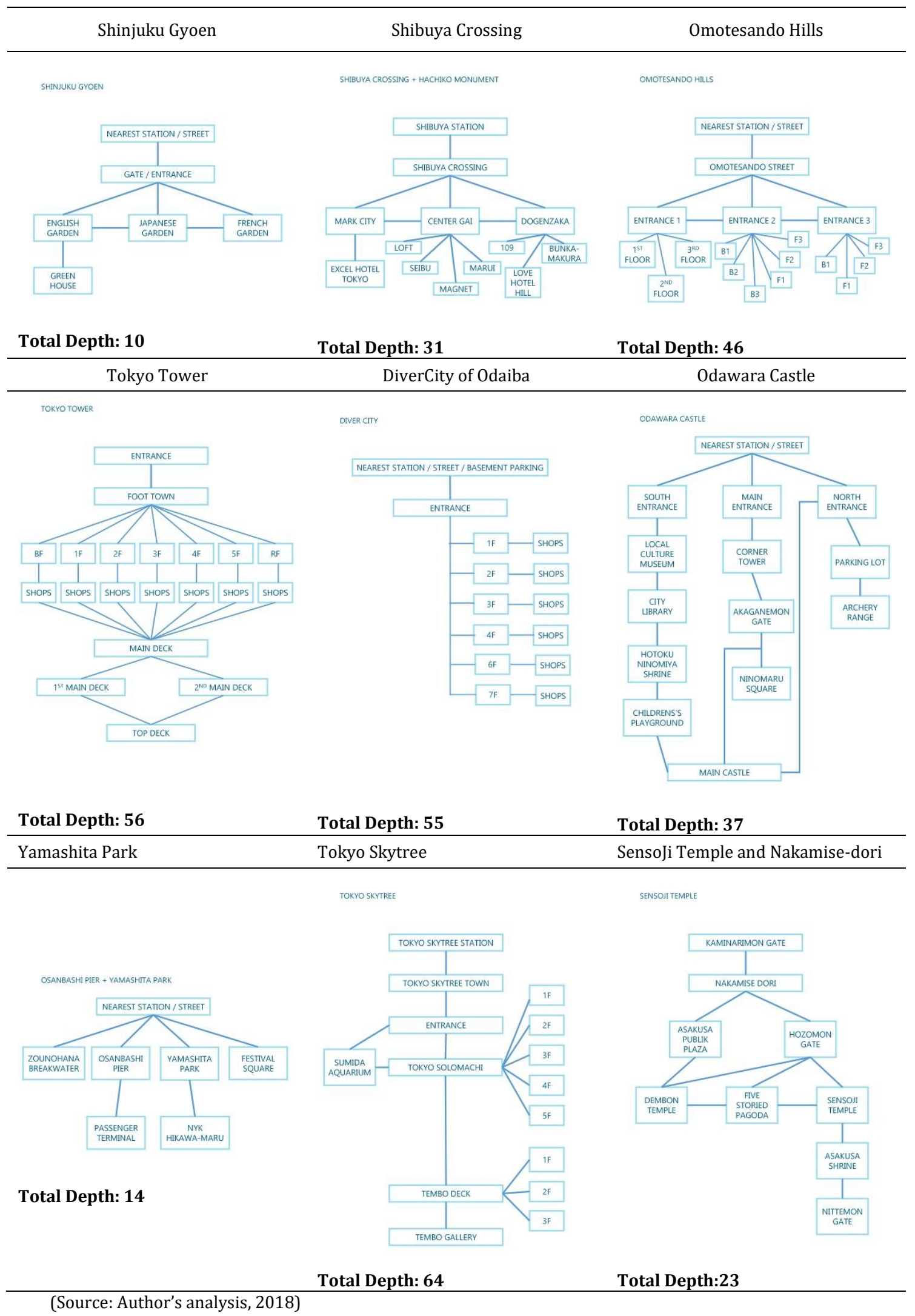

(Source: Author's analysis, 2018)

Jurnal RUAS Volume 17 No. 1 Juni 2019 ISSN 1693-3702 E-ISSN 2477-6033 


\subsection{Ambience or Atmosphere}

According to the field study, the attractions that made to the top list of Tokyo's tourist destination show various ambience or atmosphere. Several attractions are showing relaxing and calming ambience which is suitable for visitors with group or family. Several others are showing modernity and dynamic city life, such as Shibuya Crossing, Tokyo Skytree, and DiverCity, that attracts younger visitors. As the capital of Japan, Tokyo has Omotesando Hills that offers high-class shopping experience with many international brands being displayed. Attraction like Tokyo Tower and Sensoji Temple can mix more than one ambience very well. Dynamic urban life and traditional ambience is shown in SensoJi Temple where hundreds of people visit the ancient temple every day (Orcutt, 2012). Tokyo Tower successfully combines modernity of a skyscraper with traditional interior design in some shops. The relatively newly developed Yamashita Park put historical elements along its waterfront to combine the dynamic city life ambience and Japanese traditional value.

Table 4. Ambience or Atmosphere in each Tokyo's Famous Tourist Attraction

\begin{tabular}{lll}
\hline Attraction & \multicolumn{2}{c}{ Picture } \\
\hline Shinjuku Gyoen & & \\
&
\end{tabular}

(Source: Author, 2018)

Shibuya Crossing

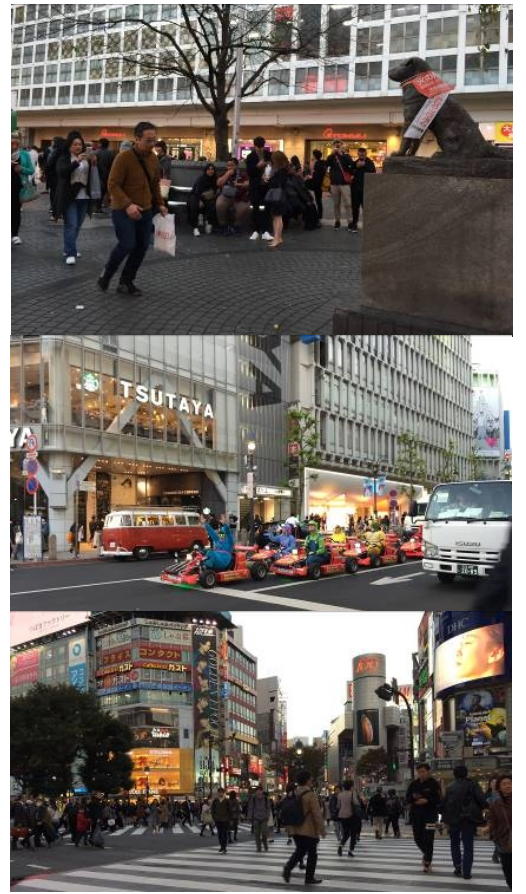

(Source: Author, 2018)
Relaxation seems to be the strong point of Shinjuku Gyoen. Shades from trees, grassy land, multi-coloured leaves, and vast openness construct a relaxing atmosphere in this place. The place is very suitable for families or visitors who travel in group. The ambience encourages people to stroll around and to take pictures.

Shibuya Crossing is always full of people, whether just passing by or admiring the Hachiko statue. The ambience of this unique five crossing shows a modern and dynamic place. Tokyo urban life, where everything moves so fast, is truly felt a this attraction 
Omotesando Hills

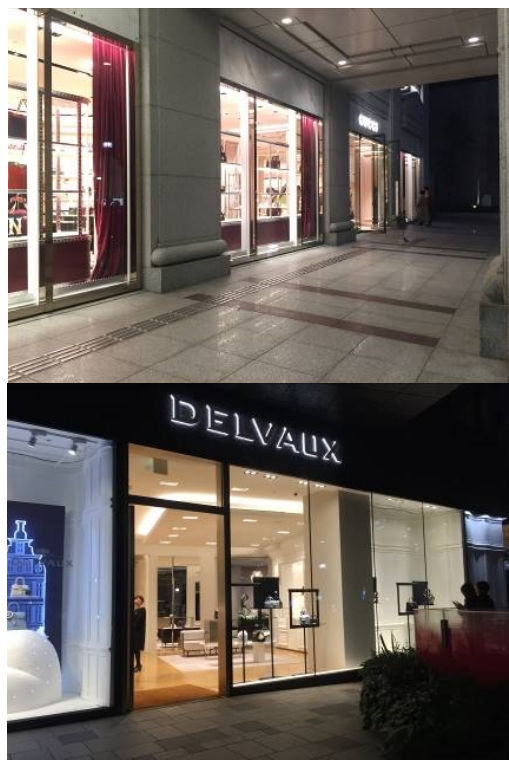

(Source: Author, 2018)

Tokyo Tower

DiverCity of Odaiba
Omotesando Hills offer an ambience of high-class shopping. Many international brands can be easily found here. The shops are well designed to enhance the luxury shopping experience

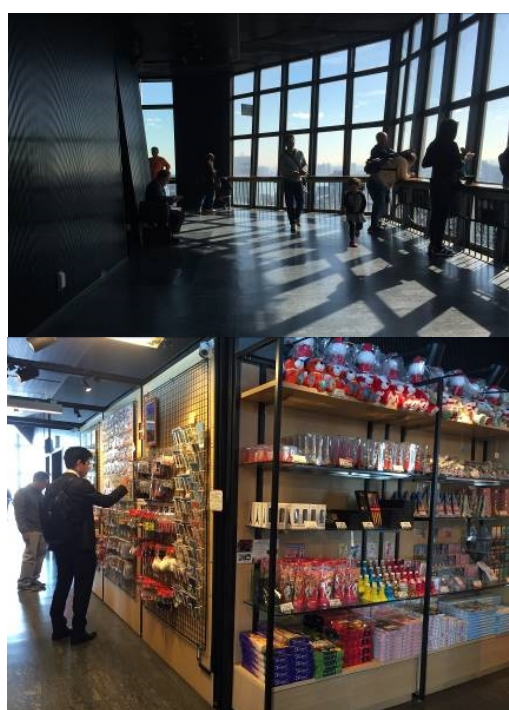

(Source: Author, 2018)

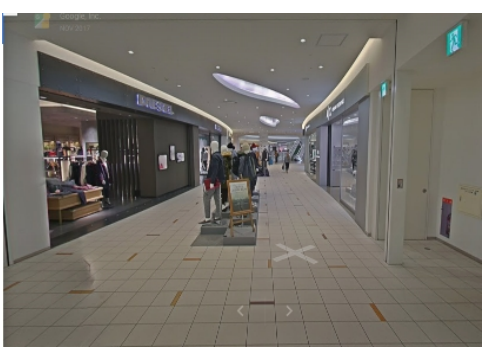

Tokyo Tower offers a mix atmosphere of modernity and warm feeling. The modernity is shown by its materials and attracts young to adult visitors. The warmness come from the natural lighting and the interior of the souvenir shop, thus attract families and younger children.

The combination of hightechnology installation on the outside and international style on the inside shops gives unique atmosphere to the mall. Hence it attracts more of younger visitors 


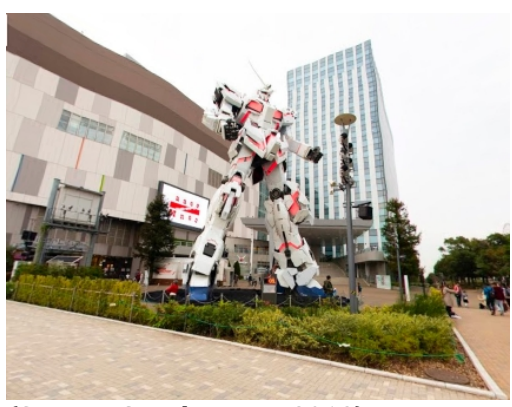

(Source: Google Maps, 2018)

Odawara Castle
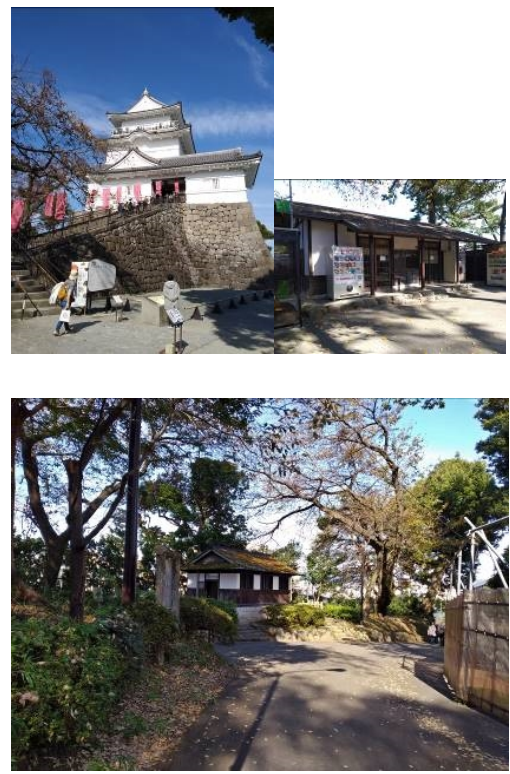

(Source: Author, 2018)

Yamashita Park

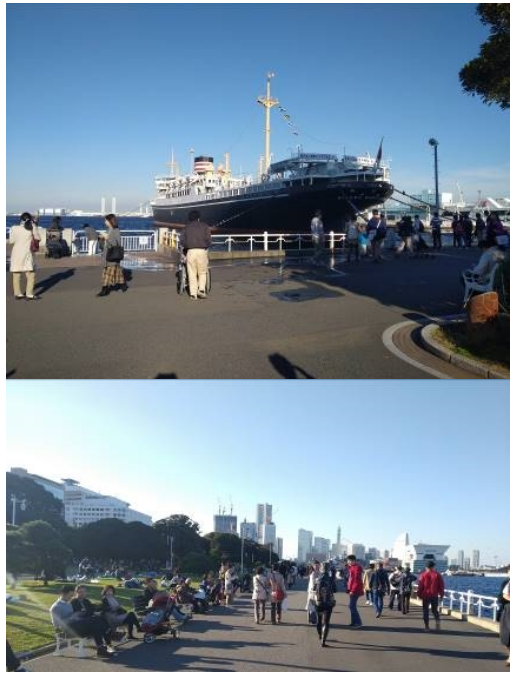

(Source: Author, 2018)
Consisted of castle from Edo period, Odawara Castle emits a strong traditional ambience. To support the castle itself, the surrounding shops are designed like the old Japanese buildings. People can enjoy the castle itself or just stroll around its vast yard.
Located in one of Tokyo's newest developed area, Yamashita Park shows how modern public park can cater for so many activities. A glimpse of historical values can be found in several spots (like the picture here shows old military vessel, indicating the history of the port city). 
Tokyo Skytree

Sensoji Temple and Nakamise-dori

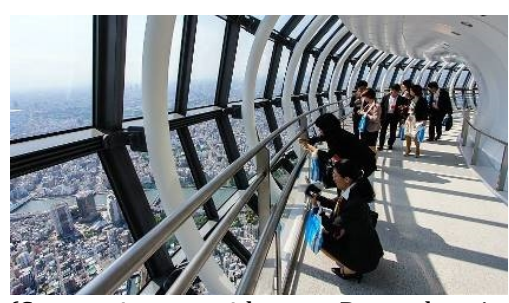

(Source: japan-guide.com, December 4, 2018)
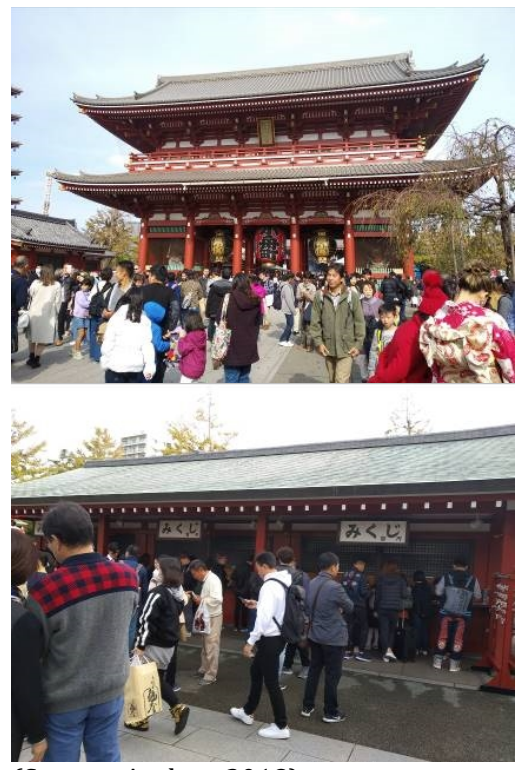

(Source: Author, 2018)
Tokyo Skytree exhibits modernity at its finest. The outdoor looks show the supertall structure whereas the indoor shows modernity through its monochromatic colour and the materials of the viewing deck.

Sensoji is like the combination of Shibuya Crossing and Odawara Castle. This place is usually heavily crowded by tourist yet the buildings are as old as Odawara castle. The robustness of the area is successful in attracting visitors from various age and group. The huge temple indicates historical and traditional value of the site.

(Source: Author's analysis, 2018)

\subsection{Limitation and Recommendation of the Study}

The main limitation of the research is the limited number of tourist attractions that is observed and analyzed. Among many attractions in Tokyo, the author classifies it into four groups. At least one example of attraction in each group is taken as the study object. However, there is no exact way yet on deciding which attraction represents its group the most. Hence, the election of the representative attraction is solely based on the popularity among travelers which data can be easily obtained. Next limitation comes from the variety of the attractions chosen for this study. Each attraction has unique physical entity that differs from one another. This makes the four analyses intended on this study might not be $100 \%$ suitable for each attraction. For example, the total depth analysis is more suitable for buildings instead of urban precinct. Lastly, technical limitation is also encountered in this study. The shortness of the trip prevents the authors to get more thorough information regarding the accessibility and amenities.

Since this research shows preliminary study on spatial character of Tokyo's famous tourist attractions, several future studies are identified. The first one is a more detailed study on specific tourist attraction to get better understanding of its spatial feature. Another interesting study will concern specifically on the role of architecture in urban tourism. This field is already widely discussed among researchers, thus creates abundant background theory regarding this matter that makes specific case study on certain precinct possible and needed. The third is to conduct comparative research of urban tourism in two different cities, for example in Tokyo and Kyoto, or even further in 
two different countries, for example Japan and Singapore. With this comparative study, the final goal would be identifying spatial character of urban tourism in broader region of Asia.

\section{Conclusion}

As a well-known example of urban tourism, Tokyo consists of several attraction points that support the tourism development of the city. Nine samples are observed in this study to formulate the contribution of its popularity in architectural perspective. Qualitative and quantitative data are presented on the previous chapter that shows both similarities and distinctions among those tourist attractions. The following points are derived from this study:

a. The provision of public realm in every study subjects is making visitors to enjoy the attractions better. Most of the attractions require the visitors to pay in order to enter more private space. However, public space is always free in all attractions. Even though the size of public space in each attraction varies, it makes paying policy to enter a specific attraction not mandatory.

b. In a busy city like Tokyo, travel efficiency is a thing that wished upon. To be able to visit several places without taking any public transport is one sign of travel efficiency. All study subjects here have at least seven smaller scale attractions within $1 \mathrm{~km}$ radius around them, so people may enjoy it after the main attraction without the use of motorized transport. Moreover, these attractions have more than one entrance, facing different streets, thus making it easier to access from more than one metro station.

c. In a matter of space complexity, the attractions listed on this study have different Total Depth (TD) value. The author believes that the difference is mainly caused by the different typology of the place. The larger the place and the more public it is, the lower the TD value is and vice versa. Attractions like parks and heritage site tend to show lower TD value indicating low complexity and hence show high space integration. On the other hand, commercial places like shopping malls tend to have higher TD value indicating high complexity and hence show low space integration.

d. Similar to space complexity, the ambience of the nine study objects show different result for each attraction. The attractions are able to offer wide range of experience, from relaxing and traditional atmosphere that suits more to those who visit with family to dynamic and high-tech atmosphere such as towers as well as shopping malls.

\section{References}

Baloglu, S., \& W.McCleary, K. (1999). A model of destination image formation. Annals of Tourism Research, 26(4), 868-897. https://doi.org/https://doi.org/10.1016/S01607383(99)00030-4

Cegar, I. (2014). ARCHITECTURE'S ROLE IN TOURISM AND CITY BRANDING. Retrieved November 29, 2018, from http://www.iaacblog.com/programs/architectures-rolein-tourism-and-city-branding_/

Dawes, M., \& Ostwald, M. J. (2013). Precise Locations in Space : An Alternative Approach to Space Syntax Analysis Using Intersection Points, 3(1), 1-11.

https://doi.org/10.5923/j.arch.20130301.01

Georgiou, M. (2006). A Topological Approach to Relational Design Problems. University College London. Retrieved from 
https://www.google.com/url?sa=t\&rct=j\&q=\&esrc=s\&source=web\&cd=2\&ved=2ah UKEwjsrYf9nPTeAhXMqY8KHdZIDDIQFjABegQIBRAC\&url=http\%3A\%2F\%2Fdiscov ery.ucl.ac.uk\%2F2919\%2F1\%2F2919.pdf\&usg=A0vVaw0y50bHkSBbGx28t_ELiWfq

Giriwati, N., Homma, R., \& Iki, K. (2016). Urban tourism : designing a tourism space in a city context for social sustainability. In The Sustainable City VIII (pp. 165-176). https://doi.org/10.2495/SC130141

Gunn, C. A. (2002). Tourism Planning: Basics, Concepts, and Cases. Psychology Press. Henderson, J. (2017). Global cities, Tokyo , urban tourism. International Journal of Tourism Cities, 3(2), 143-157. https://doi.org/10.1108/IJTC-01-2017-0006 Japan National Tourism Organization. (2017). Tokyo \& Vicinity Walking Guide. Tokyo. Kurihara, T., \& Okamoto, N. (2010). Foreign Visitor 's Evaluation on Tourism Environment, 8, 912-925.

Leheny, D. (2003). The Rules of Play: National Identity and the Shaping of Japanese Leisure. New York: Cornell University Press.

Manifesty, O. R., \& Afif, N. (2018). From Angkringan to Coworking Space : The Emergence of New Social Spaces for Young People. In The 4th International Conference on Indonesian Architecture and Planning. Yogyakarta: Universitas Gadjah Mada.

Orcutt, A. (2012). World's Most-Visited Sacred Sites. Retrieved December 6, 2018, from https://www.travelandleisure.com/slideshows/worlds-most-visited-sacred-sites

Pratt, S., Sum, W., Chan, A., Pratt, S., Sum, W., \& Chan, A. (2017). Destination Image and Intention to Visit the Tokyo 2020 Olympics among Hong Kong Generation Y. Journal of China Tourism Research, 00(00), 1-19. https://doi.org/10.1080/19388160.2016.1246272

Ranaweerage E., Arima T., Kikuchi T. (2018) Regional Characteristics of Urban Tourism in Tokyo. In: Kikuchi T., Sugai T. (eds) Tokyo as a Global City. International Perspectives in Geography (AJG Library), vol 8. Springer, Singapore

Salingaros, N. A. (2014). Complexity in Architecture and Design. Oz Journal, 36(May), 113.

Sassen, S. (2001). The Global City: New York, London, Tokyo (2nd ed.). New Jersey: Princeton University Press.

The Urban Phoenix. (2018). What If We Viewed Public Space Like Tourist Attractions? Retrieved December 2, 2018, from https://theurbanphoenix.com/2018/03/26/parksandtourism/

Tokyo Metropolitan Government. (2017). PRIME Tourist Destination City Tokyo. Tokyo. Retrieved from https://www.google.com/url?sa=t\&rct=j\&q=\&esrc=s\&source=web\&cd=2\&ved=2ah UKEwjLxYGIkfTeAhUS4o8KHdjgB9oQFjABegQICBAC\&url=http\%3A\%2F\%2Fwww.s angyo-

rodo.metro.tokyo.jp\%2Fplan\%2Ftourism\%2Fpocket_total_2018en.pdf\&usg=AOvVa w2wN4YqGtOG5-eLL5VdXMYm

Tokyo Metropolitan Government. (2018). PRIME Tourist Destination City Tokyo. Tokyo. World Tourism Cities Federation. (2017). City Tourism Performance Research Report for Case Study "Tokyo." Tokyo. 